RESEARCH ARTICLE

\title{
Quality with Integrity: Working in Partnership to Conduct a Program Review
}

Paige McKenny and *Catherine Anderson, Department of Linguistics \& Languages, McMaster University, Hamilton, Canada

Contact: canders@mcmaster.ca

\section{ABSTRACT}

Quality assurance processes often include reductive quantitative metrics that view higher education through a neoliberal lens. This paper reports on a student-faculty partnership that conducted a quality review of an undergraduate program at a large research university and shows that working in partnership brings integrity and constructive complexity to the quality assurance process. The partnership laid the groundwork for realistic enhancements in the undergraduate program by weaving multiple, authentic perspectives from student and faculty stakeholders into the review. The authors also experienced profound growth in their sense of connection to each other and to the university community. These outcomes suggest that conducting quality assurance in partnership can destabilize traditional power structures and disrupt a transactional understanding of faculty-student relationships, while also satisfying regulatory requirements.

\section{KEYWORDS}

quality assurance processes, program review, SoTL, neoliberalization, emotions

The need for institutions to be accountable to stakeholders is a powerful force shaping public higher education. Quality assessment processes can be a locus for complex conflict among stakeholders' competing goals, and quality metrics can reinforce a market-driven understanding of education. We propose that completing a quality review in partnership among students, faculty, and staff brings integrity to the process, fulfilling regulatory requirements while also honouring the experiences of those most directly engaged in undergraduate education - the students and faculty. In this paper, which documents a quality assurance (QA) partnership at a Canadian university, we show how partnership adds valuable 
complexity to QA in a way that echoes the complexity of undergraduate education and potentially disrupts the neoliberalization of the university. Furthermore, the non-traditional structure of this paper surfaces the important affective outcomes of the partnership for both authors.

It seems uncontroversial that a publicly funded institution should provide evidence of its performance, but what counts as performance? QA processes reveal which performance measures are deemed valuable by those who take the measurement (Stensaker \& Harvey, 2011). If one considers whose interests are served by university QA processes, as Wall, Hursh, and Rodgers (2014) urge, several stakeholders with distinct interests are immediately obvious. Administrators must ensure that the institution meets regulatory requirements and is appropriately funded, and faculty aim for students to learn a subject. Students seek to develop skills and master a discipline, while they and their parents want to be assured of future employment (Kezar, 2005). Furthermore, taxpayers (via government agencies) want value for their tax dollars, and employers prefer to hire graduates who require little additional training. The interests of such disparate stakeholders are not all aligned. What, then, should a quality review measure? What values are revealed by performance metrics?

One way to escape the tangle of stakeholder needs is to consider the university's overall mission. Collini (2012) and Kezar, Chambers, and Burkhardt (2005) make the case that the public university has a responsibility to serve the public good. Indeed, the final sentence of our university's mission statement asserts, "We serve the social, cultural, and economic needs of our community and our society" (McMaster University, 2003). Wall et al. (2014) argue, "If the goal of higher education is to serve the public good ...., assessment can be framed as an ethical, valuing social practice" (p. 13). From this point of view, QA can go beyond quantitative metrics to tell a story about an institution's values. A quality review provides the opportunity to illustrate the contributions that students, staff, and faculty make to the public good. And yet, Kezar (2005) documents a "mission shift" in higher education in the United States (p. 35). She argues that the academy's values have turned away from serving the public good towards the interests of the marketplace, such that Americans no longer perceive higher education to be a public benefit, but rather a means for individuals to attain employment success. In Ontario, Canada, the tension between these values is present today: public universities have committed to "preparing every student with the skills they need for the workforce ..., helping enhance the quality of life for Ontarians ...., [and] helping our economy grow" (Council of Ontario Universities, 2017, p. 4). We note that the commitment to the public good is sandwiched between two market-driven goals.

In Ontario, the interests of taxpayers, employers, students, faculty, and administrators are entangled through funding mechanisms. A sizeable proportion of each public university's operating budget comes from a provincial grant governed by the Strategic Mandate Agreement (SMA) that it negotiates with the province. These SMAs "encourage institutions to work with the government to help build a highly skilled workforce and . . focus on each institution's strengths to enhance quality and outcomes." (Province of Ontario, 2018, emphasis ours). Each SMA includes performance metrics that influence the operating grant for subsequent years. The degree to which the taxpayer funds the institution is thus directly tied to metrics that are 
explicitly linked to an understanding of the university as the training ground for workers in the capitalist marketplace.

In such a funding environment, faculty and staff have a material interest in providing evidence of the institution's quality, because operating budgets may depend directly on that evidence. The QA process therefore has the potential to reinforce or exacerbate existing power structures, as each academic unit strives to retain resources from an ever-shrinking pool. The stakes are high for students, whose academic experience relies on their program's quality, yet students rarely have a role in the decisions that influence quality. It is therefore crucial that QA processes consider students' needs.

The last decade has seen increasing attention paid to student involvement in quality assessments. For example, the revised UK Quality Code for Higher Education lists as a Core Practice that institutions "actively engage students, individually and collectively, in the quality of their educational experience" (Quality Assurance Agency [QAA], 2018, p. 3). Setting an even stronger expectation, the Quality Enhancement Framework for Scotland includes Student Engagement as one of its five pillars (QAA Scotland, n.d.) and offers a forty-page guide (Varwell, 2016) for engaging students in quality reviews. In a research study of student engagement in quality processes in the UK, about half of respondents reported that their quality review panels included student members (van der Velden, Naidoo, Lowe, Bótas, \& Pool, 2013). But in many cases these student members have observer status with little role in decision-making (Rauhvargers, Deane, \& Pauwels, 2009; Lizzio \& Wilson, 2009), while in other jurisdictions like Australia, the role of students is limited to that of data source (Shah, Hartman, \& Hastings, 2014; Weller \& Mahbubul, 2019). The EU's Standards and Guidelines for Quality Assurance (2015) specify that external quality panels should include student members and recommend that institutions' internal processes should involve students. In Ontario, the Quality Assurance Framework recommends that students be actively involved in analyzing program data and preparing a unit's self-evaluation report (Ontario Universities Council on Quality Assurance, 2010). This brief review suggests that while quality agencies are beginning to recognize the importance of involving students in QA, the nature of student involvement varies considerably across institutions.

Researchers in the Scholarship of Teaching and Learning (SoTL) (Bernstein, 2013; Gordon, 2010; Miller-Young et al., 2017; Openo et al., 2017; Poole \& Simmons, 2013) have argued that SoTL can serve as a bridge to an ethical practice of quality assessment "through which higher education can be accountable to those it directly serves" (Hutchings et al., 2013, p. 40). The work of SoTL is, after all, the work of providing evidence about learning. Not only is SoTL a means of demonstrating quality; it also can be "a subversive activity . . . that invites critical questions about education's purposes, practices, and underlying assumptions" (Boose \& Hutchings, 2016). SoTL thus offers an opportunity to engage in a QA process that can attend to complex questions about mission and values. Furthermore, good practice in SoTL "requires that inquiry into learning be conducted in partnership with students" (Felten, 2013, p. 123). In the first place, partnership is a matter of ethics: it would be unethical to exclude students from a scholarly investigation of a program's quality since they are the primary experiencers of that quality. Secondly, because student-faculty partnership is collaborative and reciprocal (CookSather, Bovill, \& Felten, 2014), it has the potential to disrupt two common views of the 
relationship between students and faculty-on the one hand, the marketized view that students are consumers and faculty members the service providers, and on the other hand, the paternalistic view that faculty members are experts who know what's best for students. Challenging these traditional power relationships is troublesome (Marquis et al., 2016; Marquis, Black, \& Healey, 2017), and the relationship among partners is complicated (Bovill, Cook-Sather, Felten, Millard, \& Moore-Cherry, 2016), but these are not reasons to shy away from partnership. Rather, the difficult, multi-faceted process of partnership parallels the messy, complex nature of undergraduate education. The very complexity of partnership allows scholars to examine questions that cannot be captured by quantitative metrics. Engaging in a quality process in partnership can thereby "provide a conceptual space in which to reflect on the nature and aims of higher education" (Healey, Flint, \& Harrington, 2014, p. 10). For QA processes to be conducted ethically, and for the process to promote justice and not simply satisfy a regulatory checklist, clearly SoTL conducted in partnership among students, faculty, and staff is vital.

The following section describes the goals of our QA project, its tasks and timeline, and the roles that each partner played. The subsequent section presents the outcomes of the project for the undergraduate programs and considers the professional outcomes that the student partners realized. The paper then takes an unconventional turn, exploring the emotional experiences of the two authors throughout the partnership. We have deliberately chosen this personal reflective style as a means of disrupting standard "objective" ways of talking about quality assessment.

\section{OUR PARTNERSHIP}

The partnership reported here took place over 18 months, involving two undergraduate student partners, one educational developer, and one faculty member. The seeds of partnership were sown when Catherine Anderson, a Teaching Professor in the Department of Linguistics and Languages at McMaster University in Hamilton, Ontario, Canada, sought support from Erin Aspenlieder, an educational developer with McMaster's Paul R. MacPherson Institute for Leadership, Innovation and Excellence in Teaching (henceforth the MacPherson Institute), for an upcoming QA review of undergraduate programs. Erin recommended that Catherine join the first cohort of scholars to complete the quality process through MacPherson's Student Partners Program. Catherine was familiar with the principles of partnership but had not worked with student partners before. Through the program, she hired Paige McKenny and Julia Varanese. Paige is a first-generation university student of non-traditional age. Having completed college-level education, she decided at age 22 to return for her Bachelor of Arts. When the partnership began, Paige was a second-year student in the Linguistics program. Julia, a traditional-aged student, was in her fourth year of the Cognitive Science of Language program. Paige and Julia had been students in Catherine's courses in the past but were not during the partnership. Their work was paid at an hourly rate by the MacPherson Institute.

The partners entered the partnership with complementary goals. Paige and Julia expressed their desire to advocate for their peers in enhancing the program and to provide an authentic view of the student perspective. They were also interested in learning about SoTL and about undergraduate education. Catherine likewise wanted the QA process to represent students' voices with integrity and hoped to lay the groundwork for meaningful enhancements 
to the undergraduate programs in Linguistics. More prosaically, she wanted to divide the labour of a daunting project.

\section{Timeline of the quality assurance process}

Our tasks and timeline were shaped by state and institutional requirements. In Ontario, every university program must undertake a quality review every eight years. The structure of the Institutional Quality Assurance Process (IQAP) is defined by the Quality Assurance Framework of the Ontario Universities Council on Quality Assurance (2010). While the details vary across universities, all IQAPs include key elements: the department prepares a self-study, external reviewers from peer institutions visit, and the university administration responds to the department's and reviewers' reports. While the process is defined at the provincial level, the responsibility for providing evidence that the program meets standards rests with the faculty and staff who design and deliver the program.

Table 1. Project timeline

\begin{tabular}{l|l}
\hline November 2016 & Catherine and Erin receive funding to hire two student partners. \\
\hline January 2017 & The team begins its work. Paige and Julia decide to conduct \\
interviews with faculty and focus groups with students. \\
Catherine begins emergency medical leave.
\end{tabular}

\section{Student roles in the IQAP partnership}

The literature provides many examples of student participation in decision-making, some of which rank participation on a linear scale. For example, Bovill and Bulley (2011) offer a "ladder of active student participation" (p. 5); on higher rungs, students and faculty negotiate 
curriculum decisions together as partners. Likewise, McKinney, Jarvis, Creasey, and Herrmann (2010) propose a continuum of roles on which the role of "collaborator/partner" has high autonomy and complexity (p. 84). We entered the partnership with aspirations for Paige and Julia to have highly autonomous roles, and the account that follows illustrates that they climbed quite high on the ladder of autonomy.

The team decided early to gather qualitative data from program students and faculty members. Because of Catherine's medical leave, Paige and Julia developed scripts for these interviews and focus groups with support from Erin. They were guided by three foundational questions: (a) "What does the program intend for our students to learn?", (b) "What and how are students learning?", and (c), "How can the faculty enhance students' experience?". With those guiding questions in mind, they crafted specific questions to ask of students and instructors. They facilitated three focus groups with undergraduates, which they audiorecorded and transcribed. They also conducted interviews with 12 faculty members, which they documented by taking extensive notes.

Once data-gathering was complete, the team proposed an initial set of codes for the transcribed data, which Paige and Julia enriched by constant comparison (Parry, 2011). In addition to coding the qualitative data, Paige and Julia also summarized findings from the university's quantitative dataset. With Catherine, they presented interim findings to the department, so that instructors could begin to address some of the student concerns that had emerged. Following the presentation, Paige and Julia collaborated in writing substantial portions of the department's self-study report. Julia wrote about accessibility in classes and about experiential learning opportunities. Paige and Julia together wrote the section evaluating how course offerings compare with the program's stated learning outcomes. Paige also wrote the section describing how students' performance is assessed. Their writing drew on their interpretations of the data they had gathered in the interviews and focus groups.

\section{PROJECT OUTCOMES}

While we initiated this project with goals related to the undergraduate programs, we also realized outcomes beyond the program, namely, professional development of the student partners and effects on the emotional state of all the partners. In the following sections, we present data from the student focus groups and instructor interviews, for which we obtained informed consent using a protocol approved by the McMaster Research Ethics Board. We also present data from ourselves, which we gathered through written reflections and a lengthy conversation. The written reflections used prompts from Marquis et al. (2016) and the conversation was guided by questions from MacPherson Institute staff.

Outcomes for the department: Investigating the linguistics programs with integrity

A primary goal of completing the IQAP in partnership was to obtain authentic data. We hoped that with student partners as facilitators, data would emerge that would not have been available to a faculty interviewer. One observation that suggests that the focus group participants perceived the student researchers as their peers is simply that they answered questions by including Paige and Julia, for example, "one of our program's strengths" and, "there can be a disconnect between us and TAs and profs" (Focus Group Participants, emphasis ours). While it is impossible to know what participants would have said to different facilitators, 
the transcripts reveal that students and faculty alike were quite candid with the student researchers. Expressing frustration about the nature of the feedback they receive, one student participant pulled no punches:

Why aren't you giving it (the midterm test) back to us? We might show it to next year's students? Well, then, make a new midterm! It shouldn't be on us to not be able to get back our midterms because they are too lazy to make a new midterm next year. (Undergraduate Focus Group)

Likewise, in considering the program's intended learning outcomes, a senior student was quite blunt:

Facilitator: Do you think that, if we knew from the start what was actually expected of us from our degree, how would that affect your experience in the program if you knew about them (the Program Learning Outcomes) from the start?

Participant 3: You'd probably be disappointed at the end of your degree, 'cause they wouldn't follow through with what you've learned. Like you're going in there expecting to learn all of these; you would be a little disappointed that you didn't do this. You weren't able to. (Undergraduate Focus Group)

These frank comments suggest that we achieved our goal of eliciting authentic data from students. Furthermore, we found that having the student researchers interview instructors kept the focus of the interview on the student experience and led faculty to reflect in ways that might not have occurred in a context that included their colleagues. For example, in response to the question, "How does our department support faculty in considering program learning outcomes in course design and delivery?", a faculty member who was new to teaching described feeling unsupported in developing courses. They consulted colleagues for advice but were reluctant to bother people. The instructor would have liked a mentor, "some authority, someone responsible to use as a first line of approach" to support them in developing their teaching practice (Faculty Interview). Similarly, several instructors admitted to the student interviewers that the faculty collectively do not talk enough about the ways that different courses connect to each other, nor about how writing is taught and assessed.

These findings, which highlight some shortcomings of the program, might not have emerged from conventional data-gathering instruments like written surveys. The student partners played a crucial role in uncovering areas for improvement.

Although we initially encountered some resistance from faculty members about the project, in the end we discovered that our work had transformative effects among instructors. When we presented our initial findings to the department in August 2017, we focused on current students' experience of the program, highlighting strengths and suggesting potential changes to improve the student experience. At the end of that meeting, one instructor commented, "That wasn't as bad as I had feared!", revealing that they had perhaps dreaded hearing a list of complaints. One year later, every faculty member participated in an exercise to link the program's learning outcomes to outcomes for individual courses. The change in attitude from resistance to full participation suggests that the process by which we conducted 
the quality review succeeded in honouring faculty members' experiences and that instructors saw the value of engaging in ongoing quality enhancement.

These outcomes make us confident in concluding that we achieved our goals of gathering authentic data from student and faculty stakeholders and of setting the stage for meaningful enhancements to the Linguistics programs.

\section{Outcomes for partnership: Developing professional skills in partnership}

At the outset of the project, Paige and Julia expressed their goal of advocating for their peers. The manner in which they did so grew and changed throughout the project as they gained experience and confidence. Bovill (2017) offers a participation matrix as "a way to be transparent about the different roles of different actors at different stages of a SaP project" ( $p$. 3). In this project, the student partners' roles were more complex than that of researcher-they also took on the roles of consultants and representatives (Bovill et al., 2016). They found that instructors wanted to discuss their teaching methods, consulting the student partners for feedback about their courses. Paige and Julia were also natural representatives of the student voice in two ways: while they offered their individual voices at every stage, they also represented the collective voice because they had gathered and analyzed the data from their fellow students (cf. Little \& Williams, 2010; Crawford, Horsley, \& Parkin, 2019).

It is clear that the student partners' roles involved a high degree of time and effort, placing their contributions on the high rungs of Elassy's (2013) model of student involvement in $\mathrm{QA}$, where the topmost contributions include meeting external reviewers and sharing in the writing process. Their contributions to the self-study (described above) demonstrate that Paige and Julia grew into their roles of co-researchers, not just gathering and reporting data as a research assistant might do, but interpreting it and drawing sophisticated conclusions about enhancements to student learning. Their conclusions were informed not only by their individual experiences as students, but by their understanding of the literature and by their deep familiarity with their data.

In reflecting on their own professional development, both student partners remarked on how the project had influenced their identities as scholars:

I've always been really interested in seeing how people learn, and in all of my grad school applications I've been able to say I want to work with pedagogy. So this project has really solidified something that I feel like I can do and I can do well because there's such a big importance for it. (Reflective Conversation, Julia)

Before I was on this project I never thought that there was something I was more interested in than Linguistics and that was my plan for grad school, but now I'm likepedagogical research grad school-l'm obsessed about it. (Reflective Conversation, Paige)

Paige and Julia's multi-faceted roles in this project brought immense value to the QA process, and also contributed to their growth in research skills, confidence, and their openness to SoTL research in the future. 


\section{REFLECTING ON AFFECTIVE OUTCOMES}

Besides the benefits to the Linguistics programs, we found that our partnership had profound emotional effects on each of us. While it is rare for academic papers to acknowledge the authors' emotional state, we do so in response to Felten's (2017) urging that "focusing on the emotional dimensions of partnerships will shine new light on the dynamic processes and the powerful outcomes of this work" (p. 3). Therefore, in this section of the paper, we move from an objective reporting of our findings to a subjective account that mingles primary data from structured reflections with interpretation shaped by our experience. We follow Cates, Madigan, and Reitenauer (2018) by writing in the first-person singular to acknowledge that our experiences differed because of our roles and status. We are also mindful that the SaP literature tends to be biased towards reporting positive outcomes (Mercer-Mapstone et al., 2017; Marquis et al., 2017). In our discussion we have striven to be honest about both the challenges and the rewards of partnership.

\section{Paige's experience as a student partner}

The experience of working in partnership for program review was one full of growth and change. At the outset, my responses to reflective prompts expressed apprehension mixed with enthusiasm to be involved in the project:

I am nervous that I will not produce adequate work. I think this is simply due to the fact that I have never done anything like this before. . . . I feel very much responsible for the outcome of the work I will be asked to produce. (Written Reflection)

Additionally, coming into this project as a student new to both the university environment and to McMaster was a challenge. I had doubts that I could be an adequate member of the team given my limited knowledge of the program at the time. I struggled with feeling like I could assert myself and my ideas because, as a student, being in a position where my input was sought after was jarring and unfamiliar. Negotiating the dynamic of being on the same level as a respected faculty member and still needing that person's assistance at times was also difficult. Initially, I felt that working in partnership implied an expectation of some preexisting knowledge on my part of the tasks that I needed to complete, and I was reluctant to ask for help. When I sought advice, however, Catherine assured me that needing assistance is OK and even expected. It took time and practice bringing forward ideas and having them validated and included for me to "buy-in" and feel like an equal partner, but relinquishing the idea that I was expected to have everything figured out was immensely transformative for me.

Over time, my concerns about the quality of my work and meaningfulness of my contributions all but vanished. Good communication and weekly meetings meant that we could check in often and candidly about issues or concerns. Given Catherine's absence, Julia and I were required to step up to the plate in a radical way. This radical independence garnered us the chance to be in charge and left no room for doubt that our contributions to the project were meaningful. During her absence, I wrote:

The primary challenge in the beginning of the term was the absence of our supervisor. I feel that with her direction things may have felt like they were going more smoothly. In reality, things were very smooth ... and our main challenges have been very minimal.

(Written Reflection) 
Seeing that our contributions were so important to the project overall was at once validating and motivating. The more we accomplished the more confident we became.

As a student at a large university, it is easy to feel as though you could never make a difference. Being part of the partnership greatly enriched my sense of belonging in the program community and, by extension, how much I felt I could make an impact. My written reflection from that time shows how I became aware of this enrichment: "It's really helped me integrate myself into the McMaster community. I know so many more of my peers now which is amazing and the faculty as well which is an invaluable resource" (Written Reflection). Christie, Tett, Cree, Hounsell, and McCune (2008) show that the transition to university is an inherently jarring emotional experience, especially for students from equity-seeking backgrounds. I found that with my improved sense of belonging to and understanding of the university community came empowerment about my role in my education. I was able to feel that I, as a student, had a valuable perspective that was worth being included when considering the quality of the program and that, by advocating for that perspective, I could have an impact on my own experience and that of my peers.

Moving through my self-doubt in the context of working in partnership was an important process in my experience of the partnership. To go from lacking confidence in my role to feeling valued, not only by my fellow team members but by the faculty at large, was a vital and transformative milestone. Akin to the findings of Cates et al.(2018), during and after my involvement in the project, I felt more enmeshed in my university experience than I ever expected. Between finding a mentor, colleague, and friend in Catherine and becoming more closely acquainted with my peers, I began to feel a sense of real connection where previously I had felt isolated and unsure of myself. After my experience on the project, I felt at ease within the department and with faculty. Collaborating with students, staff, and faculty to reach a common and mutually beneficial goal made way for my own reconceptualization of the university environment as one that is rich with opportunity for connection.

\section{Catherine's experience as a faculty partner}

A recurring theme in the literature is that a functional partnership requires a sizeable investment of time (Acai et al., 2017; Bovill, Morss, \& Bulley, 2009; Curran, 2017; Marquis et al., 2017). To be honest, my first impetus for hiring through the Student Partners Program was to reduce the amount of time I would spend on the IQAP. As it turns out, because of my illness, I did indeed spend less time than I expected, because I was simply unable to work for about three months. Paige writes above about how my absence affected the students' experience. When I returned to work, one of my challenges was to align my schedule with the rest of the partners. The week that I returned to work, I wrote:

My original role was as the one who was in charge of the project. Now my role seems to be more of a cheerleader from the sidelines - the student partners have seized the reins and I'm just nudging here and there. (Written Reflection)

I am usually a solo practitioner, but for the partnership to proceed, I had to meet regularly with the team and complete my tasks according to the team's schedule. This challenge is not unique 
to partnership-it is inherent to any work conducted in teams - but I occasionally felt frustrated by the loss of autonomy.

A second challenge that arose repeatedly for me was negotiating the boundaries of professionalism in our conversations about the Linguistics programs. The QA process necessarily involved critique, as the team identified areas for improvement. When the student partners reported issues that their peers had pointed out, I struggled to suppress my personal response and to respond as a researcher instead. In some cases, when Paige and Julia described a student complaint, I felt defensive and wanted to explain why faculty did things that way. At other times, I wanted to join the students in griping about a course or even about a colleague. Neither reaction is fair to the student partners - since they were both still enrolled in the program we were researching, they had to continue their own relationships with their professors and peers, and my comments could have made that more difficult for them.

In struggling to reconcile my partner and professor roles, I experienced humbling reminders that it is not always necessary for me to make all the decisions. At one point, I asserted without much thought that a standard questionnaire would suffice for surveying alumni. But Paige suggested that we add specific questions about the program learning outcomes. At the time I wrote: "I overlooked something important to the project, and it was the student partner's question that brought me back on course" (Written Reflection).

On another occasion, Paige and I were preparing a conference abstract. Wanting to finish the task in our scheduled time, I rushed us through drafting an adequate abstract and gave it a utilitarian title. Paige invested more time and added creativity and energy to both the abstract and the title (see McKenny et al., 2017). These interactions reminded me of CookSather, Bovill, and Felten's (2014) words: partnership "means following where students lead, perhaps to places we may not have imagined or been to before" (p. 8).

Although discerning the ways that my roles as partner and professor differed was sometimes challenging, I also discovered that working in partnership brought profound emotional rewards. The following excerpt illustrates one such reward:

There are some components of a faculty member's job labeled as service to the university: most of those jobs are not that much fun. Often they're boring grunt work. So to have fun with you guys and get valuable data . . . to be able to address these questions with integrity, to have an alignment within myself between doing my job with integrity to my values and being fair and authentic to students and to have fun doing it? I just think that's the luckiest altogether. (Reflective Conversation)

Within the space of about eight months, my attitude towards the IQAP had shifted from dread to enjoyment, thanks to the energy and good cheer of the student partners.

Being able to complete an onerous service task in good spirits is remarkable enough, but the emotional value of the partnership extended farther still. Pointing out that "learning, teaching, and working in institutions of higher education can be compartmentalized, demoralizing, and alienating experiences," Cates et al. (2018) show how working in partnership can create caring relationships, alleviate loneliness, and bring meaning to academic work ( $p$. 34). Our partnership began with feelings of affinity-Paige and Julia had taken my courses, and 
we knew that we liked each other-but the affective outcomes that Cates et al. (2018) describe take a substantial investment of time and energy. After the Summer 2017 semester, the nature of our partnership shifted when Julia graduated and Erin began a one-year leave. The tasks of gathering and analyzing data were done, and what remained was to write. Paige and I met weekly to write together, and this quiet time naturally led to more personal conversations. In one of these conversations we came out to each other as queer women, crossing another threshold between being colleagues and being friends. The ensuing conversations, while retaining some typical professor-student mentoring, also included mutual support through shared experiences of isolation in the university. In my 2018 promotion dossier, I wrote: "in a career that can often be thankless and overwhelming, my experience has been that interacting with students as a partner in their learning, and valuing the fullness of their experience in this learning community, has brought genuine joy to my work."

\section{AN INVITATION FOR FUTURE PRACTICE}

Our account of completing a QA review in partnership reveals themes of identity, community, authenticity, and integrity-themes that are not typical of quality assurance processes. Paige's reflection draws our attention to the effects of the partnership on her identity as a university student. As a first-generation student, when Paige first began her studies, she felt like an outsider in the university. Her reflection eloquently shows how working as a partner enabled her to come into her own as a member of the university community, both in developing concrete research and collaboration skills, and in her growing confidence in the value of her work. Her experience echoes those described by Cook-Sather's (2018) participants: student partners who were members of equity-seeking groups reported experiencing an affective change in how they related to faculty and to their fellow students and an evolution in their awareness of their agency in learning. Previous studies have found that faculty partners tend to report the ways that partnership has benefited their projects, rather than its effects on themselves personally (Marquis et al., 2016). Countering that tendency, Catherine's reflection emphasizes the personal and emotional consequences of the partnership. Specifically, she found that partnering with students enriched her sense of the university as a community and lessened her feelings of isolation. And although this paper has not explored Julia's reflections on the partnership, a quote from our final conversation before she left the project shows that she also perceived her role as richly entwined with the community:

I was able to really reflect on the last four years and how much this program has shaped me. ... It honestly means the world to me, so to be able to make that even better for [future students], it just warms my heart. I love it. (Reflective Conversation)

The fact that this partnership created a stronger sense of community for each of us offers evidence for Wijaya Mulya's (2018) argument that the collegiality and mutuality of partnership offer a mode of resistance to the neoliberalization of the university.

In addition to the powerful sense of community that grew among the partners, we have shown that partnership is effective in identifying areas for enhancement in undergraduate programs. We incorporated students' accounts of their learning experiences in complex ways that extended beyond numerical satisfaction scores. The students' comments were not always pleasant, but we discovered that faculty members were willing to take them seriously, perhaps 
because of the authentic way they themselves had participated in the process. Furthermore, having student partners collect the qualitative data avoided an ethical conflict - if faculty members had invited students to focus groups, it is possible that students would have felt obliged to participate and to provide positively-biased data. And Paige and Julia's substantial contributions to writing the self-study ensured that the report incorporated multiple perspectives (Cook-Sather, 2014).

This paper opened by considering the ways that QA processes can reinforce a neoliberal understanding of the university by relying on reductive quantitative metrics. Initially, we had concerns about the tension between regulatory compliance and our desire for authenticity. While we cannot conclude that our IQAP partnership resolved that tension completely, we can perhaps offer hope that the tension can be relaxed. We can say with confidence that we completed the QA process in a way that met our standards of integrity, while satisfying provincial and university regulations. By partnering to gather data, write the self-study, meet with reviewers, and respond to their report, we told a complex, authentic story that honoured the experiences of students and faculty and challenged the consumerist view of post-secondary education. We encourage others to strive for the same by engaging in student-faculty partnership for quality assurance.

All participants gave informed consent to participate using a protocol reviewed and approved by the McMaster Research Ethics Board.

\section{ACKNOWLEDGEMENTS}

The authors gratefully acknowledge the support of the Paul R. MacPherson Institute for Leadership, Innovation and Excellence in Teaching. We thank the reviewers for their thoughtful feedback and offer special thanks to Erin Aspenlieder for advising us on an earlier version of this paper.

\section{NOTE ON CONTRIBUTORS}

Paige McKenny completed her Bachelor of Arts in Linguistics and Languages at McMaster University in 2019. She has been involved in partnership projects since 2017 with a focus on enhancing quality assurance processes. She is currently pursuing her MA in Applied Linguistics.

Catherine Anderson is a Teaching Professor in Linguistics at McMaster University. Her teaching and SoTL interests include team-based learning, open educational resources, accessibility, and partnerships.

\section{REFERENCES}

Acai, A., Akesson, B., Allen, M., Chen, V., Mathany, C., McCollum, B., Spencer, J., \& Verwood, M. (2017). Success in student-faculty/staff SoTL partnerships: Motivations, challenges, power, and definitions. Canadian Journal for the Scholarship of Teaching and Learning, 8(2), 1-20. https://doi.org/10.5206/cjsotl-rcacea.2017.2.8 
Bernstein, D. (2013). How SoTL-active faculty members can be cosmopolitan assets to an institution. Teaching \& Learning Inquiry, 1(1), 35-40. https://doi.org/10.20343/teachlearninqu.1.1.35

Boose, D., \& Hutchings, P. (2016). The scholarship of teaching and learning as a subversive activity. Teaching \& Learning Inquiry, 4(1), 1-12. https://doi.org/10.20343/teachlearninqu.4.1.6

Bovill, C. (2017). A framework to explore roles within student-staff partnerships in higher education: Which students are partners, when, and in what ways? International Journal for Students as Partners, 1(1). https://doi.org/10.15173/ijsap.v1i1.3062

Bovill, C., \& Bulley, C. (2011). A model of active student participation in curriculum design: Exploring desirability and possibility. In C. Rust (Ed.), Global theories and local practices: Institutional, disciplinary and cultural variations. (pp. 176-188). Oxford: Oxford Brookes University: Oxford Centre for Staff and Learning Development. Retrieved from http://eprints.gla.ac.uk/57709/

Bovill, C., Cook-Sather, A., Felten, P., Millard, L., \& Moore-Cherry, N. (2016). Addressing potential challenges in co-creating learning and teaching: Overcoming resistance, navigating institutional norms and ensuring inclusivity in student-staff partnerships. Higher Education, 71(2), 195-208. https://doi.org/10.1007/s10734-015-9896-4

Bovill, C., Morss, K., \& Bulley, C. J. (2009). Should students participate in curriculum design? Discussion arising from a first year curriculum design project and a literature review. Pedagogic Research in Maximising Education, 3(2), 17-26. Retrieved from http://eprints.gla.ac.uk/8660/

Cates, R. M., Madigan, M. R., \& Reitenauer, V. L. (2018). 'Locations of possibility': Critical perspectives on partnership. International Journal for Students as Partners, 2(1), 33-46. https://doi.org/10.15173/ijsap.v2i1.3341

Christie, H., Tett, L., Cree, V. E., Hounsell, J., \& McCune, V. (2008). 'A real rollercoaster of confidence and emotions': Learning to be a university student. Studies in Higher Education, 33(5), 567-581. https://doi.org/10.1080/03075070802373040

Collini, S. (2012). What are universities for? London: Penguin Books.

Cook-Sather, A. (2014). Multiplying perspectives and improving practice: What can happen when undergraduate students collaborate with college faculty to explore teaching and learning. Instructional Science, 42(1), 31-46. https://doi.org/10.1007/s11251-013-9292-3

Cook-Sather, A. (2018). Listening to equity-seeking perspectives: How students' experiences of pedagogical partnership can inform wider discussions of student success. Higher Education Research \& Development, 37(5), 923-936. https://doi.org/10.1080/07294360.2018.1457629

Cook-Sather, A., Bovill, C., \& Felten, P. (2014). Engaging students as partners in learning and teaching: A guide for faculty. San Francisco, CA: Jossey-Bass.

Council of Ontario Universities. (2017). Partnering for a better future for Ontario. Toronto: Council of Ontario Universities. Retrieved from https://ontariosuniversities.ca/reports/partnering-better-future-ontario 
Crawford, K., Horsley, R., \& Parkin, E. (2019). How can students engage in assuring the quality of university teaching? In R. Ellis \& E. Hogard (Eds.), Handbook of quality assurance for university teaching (pp. 166-177). New York: Routledge.

Curran, R. (2017). Students as partners-good for students, good for staff: A study on the impact of partnership working and how this translates to improved student-staff engagement. International Journal for Students as Partners, 1(2). https://doi.org/10.15173/ijsap.v1i2.3089

Elassy, N. (2013). A model of student involvement in the quality assurance system at institutional level. Quality Assurance in Education, 21(2), 162-198. https://doi.org/10.1108/09684881311310692

ESG. (2015). Standards and guidelines for quality assurance in the European Higher Education Area (ESG). Brussels: European Association for Quality Assurance in Higher Education. Retrieved from https://enqa.eu/wp-content/uploads/2015/11/ESG 2015.pdf

Felten, P. (2013). Principles of good practice in SoTL. Teaching \& Learning Inquiry, 1(1), 121-125. Retrieved from https://journalhosting.ucalgary.ca/index.php/TLI/article/view/57376/43149

Gordon, G. (2010). SoTL and the quality agenda. International Journal for the Scholarship of Teaching and Learning , 4(2). https://doi.org/10.20429/ijsotl.2010.040203

Healey, M., Flint, A., \& Harrington, K. (2014). Engagement through partnership: Students as partners in learning and teaching in higher education. York: Higher Education Academy. Retrieved from https://www.heacademy.ac.uk/knowledge-hub/engagement-throughpartnership-students-partners-learning-and-teaching-higher

Hutchings, P., Borin, P., Keesing-Styles, L., Martin, L., Michael, R., Scharff, L., Simkins, S., \& Ismail, A. (2013). The scholarship of teaching and learning in an age of accountability: Building bridges. Teaching \& Learning Inquiry, 1(2), 35-47. https://doi.org/10.20343/teachlearninqu.1.2.35

Kezar, A. J. (2005). Challenges for higher education in serving the public good. In A. J. Kezar, A. C. Chambers, \& J. C. Burkhardt (Eds.), Higher education for the public good: Emerging voices from a national movement (pp. 23-42). San Francisco, CA: Jossey-Bass.

Kezar, A. J., Chambers, A. C., \& Burkhardt, J. C. (Eds.). (2005). Higher education for the public good: Emerging voices from a national movement. San Francisco, CA: Jossey-Bass.

Little, B., \& Williams, R. (2010). Students' roles in maintaining quality and in enhancing learning: Is there a tension? Quality in Higher Education, 16(2), 115-127. https://doi.org/10.1080/13538322.2010.485740

Lizzio, A., \& Wilson, K. (2009). Student participation in university governance: The role conceptions and sense of efficacy of student representatives on departmental committees. Studies in Higher Education, 34(1), 69-84. https://doi.org/10.1080/03075070802602000

Marquis, E., Puri, V., Wan, S., Ahmad, A., Goff, L., Knorr, K., Vassileva, I., \& Woo, J. (2016). Navigating the threshold of student-staff partnerships: A case study from an Ontario teaching and learning institute. International Journal for Academic Development, 21(1), 4-15. https://doi.org/10.1080/1360144X.2015.1113538 
Marquis, E., Black, C., \& Healey, M. (2017). Responding to the challenges of student-staff partnership: The reflections of participants at an international summer institute. Teaching in Higher Education, 22(6), 720-735. https://doi.org/10.1080/13562517.2017.1289510

McKenny, P., Varanese, J., \& Anderson, C. (2017, November). Program review: Nightmare? or dream come true with student-staff-faculty partnerships! Paper presented at Research on Teaching \& Learning, Hamilton, ON.

McKinney, K., Jarvis, P., Creasey, G., \& Herrmann, D. (2010). A range of student voices in the scholarship of teaching and learning. In C. Werder \& M. M. Otis (Eds.), Engaging student voices in the study of teaching and learning (pp. 81-95). Sterling, VA: Stylus Publishing.

McMaster University. (2003). Mission and vision. Retrieved from https://president.mcmaster.ca/mission-and-vision/

Mercer-Mapstone, L., Dvorakova, S. L., Matthews, K. E., Abbot, S., Cheng, B., Felten, P., Knorr, K., Marquis, E., Shammas, R., \& Swaim, K. (2017). A systematic literature review of students as partners in higher education. International Journal for Students as Partners, 1(1). https://doi.org/10.15173/ijsap.v1i1.3119

Miller-Young, J. E., Anderson, C., Kiceniuk, D., Mooney, J., Riddell, J., Schmidt Hanbidge, A., \& Ward, V. (2017). Leading up in the scholarship of teaching and learning. Canadian Journal for the Scholarship of Teaching and Learning, 8(2), 1-17. https://doi.org/10.5206/cjsotl-rcacea.2017.2.4

Ontario Universities Council on Quality Assurance. (2010). Quality assurance framework. Toronto: Ontario Universities Council on Quality Assurance. Retrieved from https://oucqa.ca/resources-publications/quality-assurance-framework/

Openo, J. A., Laverty, C., Kolomitro, K., Borin, P., Goff, L., Stranach, M., \& Gomaa, N. (2017). Bridging the divide: Leveraging the scholarship of teaching and learning for quality enhancement. Canadian Journal for the Scholarship of Teaching and Learning, 8(2), 118. https://doi.org/10.5206/cjsotl-rcacea.2017.2.6

Parry, K. W. (2011). Constant comparison. In M. Lewis-Beck, A. Bryman, \& T. Futing Liao (Eds.), The SAGE encyclopedia of social science research methods. Thousand Oaks, CA: Sage Publications. https://doi.org/10.4135/9781412950589

Poole, G., \& Simmons, N. (2013). Contributions of the scholarship of teaching and learning to quality enhancement in Canada. In R. Land \& G. Gordon (Eds.), Enhancing quality in higher education: International perspectives (pp. 118-128). London: Routledge.

Province of Ontario. (2018). College and university strategic mandate agreements, 2017-2020. Retrieved from https://www.ontario.ca/page/college-and-university-strategic-mandateagreements-2017-2020

Quality Assurance Agency. (2018). The revised UK quality code for higher education. Gloucester: Quality Assurance Agency UK Standing Committee for Quality Assessment. Retrieved from https://www.qaa.ac.uk/quality-code

Quality Assurance Agency Scotland. (n.d.). Quality enhancement framework. Retrieved from https://www.qaa.ac.uk/scotland/quality-enhancement-framework

Rauhvargers, A., Deane, C., \& Pauwels, W. (2009). Bologna process stocktaking report. Leuven/Louvain la Neuve: Bologna Follow-up Group Stocktaking Working Group. 
Retrieved from http://www.ehea.info/pid34367/implementation-and-nationalreports.html

Shah, M., Hartman, K., \& Hastings, G. (2014). Partners or opponents: The engagement of students in a compliance driven quality assessment. Perspectives: Policy and Practice in Higher Education, 18(1), 20-28. https://doi.org/10.1080/13603108.2013.835288

Stensaker, B., \& Harvey, L. (2011). Accountability in higher education: Global perspectives on trust and power. New York: Routledge.

van der Velden, G. M., Naidoo, R., Lowe, J. A., Bótas, P. C. P., \& Pool, A. D. (2013). Student engagement in learning and teaching quality management. Gloucester: Quality Assurance Agency for Higher Education. Retrieved from http://www.bath.ac.uk/learningandteaching/pdf/student engagement/Project Report 11.9.2013.pdf

Varwell, S. (2016). Engaging students in Institution-led review: A practice guide for universities and students' associations. Retrieved from https://www.sparqs.ac.uk/upfiles/ILR\%20Practice\%20Guide.pdf

Wall, A. F., Hursh, D., \& Rodgers III, J. W. (2014). Assessment for whom: Repositioning higher education assessment as an ethical and value-focused social practice. Research \& Practice in Assessment, 9, 5-17. Retrieved from http://www.rpajournal.com/assessment-for-whom-repositioning-higher-educationassessment-as-an-ethical-and-value-focused-social-practice/

Weller, S., \& Mahbubul, A. (2019). The student role in quality: From data source to partner and back again. In R. Ellis \& E. Hogard (Eds.), Handbook of quality assurance for university teaching (pp. 196-207). New York: Routledge.

Wijaya Mulya, T. (2018). Contesting the neoliberalisation of higher education through studentfaculty partnership. International Journal for Academic Development, 1, 86-90. https://doi.org/10.1080/1360144X.2018.1520110 